\section{B A Institute of \\ YK Business Administration \\ 帘 \\ Karachi \\ Leadership and Ideas for Tomorrow}

\section{Business Review}

Volume 1 Issue 1

July - December 2006

$7-1-2006$

\title{
Socioeconomic status as a predictor of marital adjustment in working women
}

\author{
Zeenat Ismail \\ Institute of Business Administration, Karachi, Pakistan \\ Kausar Ansari
}

Follow this and additional works at: https://ir.iba.edu.pk/businessreview

Part of the Economics Commons

c) (i)

This work is licensed under a Creative Commons Attribution 4.0 International License.

\section{Recommended Citation}

Ismail, Z., \& Ansari, K. (2006). Socioeconomic status as a predictor of marital adjustment in working women. Business Review, 1(1), 29-44. Retrieved from https://doi.org/10.54784/1990-6587.1093

This article is brought to you by iRepository for open access under the Creative Commons Attribution 4.0 License and is available at https://ir.iba.edu.pk/businessreview/vol1/iss1/5. For more information, please contact irepository@iba.edu.pk. 


\title{
ARTICLE \\ Socioeconomic Status as a Predictor of Marital Adjustment in Working Women
}

\author{
Zeenat Ismail \\ Kausar Ansari
}

\begin{abstract}
The purpose of the present research was to determine the extent to which Socioeconomic Status in Pakistani scenario can predict Marital Adjustment with special reference to working women. After detailed literature review it was hypothesized that Marital Adjustment would be more among working women of high Socioeconomic Status as compared to working women of low and middle Socioeconomic Status. Sample of the present research consisted of 150 married working women divided into three groups of subjects each consisting of fifty women. These groups comprised of low, middle and high socioeconomic classes. Dyadic Adjustment Scale was administered in order to measure Marital Adjustment of the entire sample. One way Analysis of Variance (ANOVA) was done to compare the difference in the level of Marital Adjustment of working women belonging to low, middle and high Socioeconomic Status. However the difference between the Marital Adjustments of the three socioeconomic groups was found to be insignificant.
\end{abstract}

\section{INTRODUCTION}

T arital Adjustment is defined as 'the state in which there is an over all feeling in 1 husband and wife of happiness and satisfaction with their marriage and with each other' (Sinha \& Mukerjee, 1990). It therefore calls for experiencing satisfactory relationship between spouses characterized by mutual concern, care, understanding and acceptance. All the marriages are aimed at happiness in one or another way. Most couples become married filled up with expectations. Some of the expectations will be realistic while others unrealistic. This is due to the complex nature of marriage and each individual is as complex as a universe. Therefore, in marriage two universes come together.

Marital satisfaction appears to be an important determinant of psychological wellbeing. Marital distress has been associated with a host of psychological difficulties, particularly depression (Beach, Whisman, and O'Leary, 1994) and marital problems are the most common complaints of those seeking help from mental health clinics (O'Leary and Smith, 1991).

According to Spanier and Cole (1976), Marital Adjustment is a process, the outcome of which is determined by the degree of: a) troublesome marital differences, b) interspousal tensions and personal anxiety, c) marital satisfaction d) dyadic cohesion, e) consensus on matters of importance to marital functioning. 
The question of what makes some people more adjusted in their marriages and others dissatisfied has been considered by many. The areas that have been explored are rather complex. Many powerful influences on marriage and family spring from the existence of clearly identifiable social classes. Our Socioeconomic Status is measured by factors such as the occupations of our parents, their education, where we live, what the family income is, the source of the income (salary, investments, a trust fund) and, if our parents have money, how long they have had it (Kahl, 1957; Warner, Weeken and Ecls, 1949).

It is an indisputable sociological fact that social class is one of the most important and defining characteristics of our lives. Social class influences quantifiable characteristics such as age at marriage, fertility and life expectancy. Furthermore, the position one holds in the social class hierarchy also determines life-style characteristics. Social class, like sex and race, is a variable that sociologists consistently examine in research on the family. In both quantitative and qualitative studies, family scholars try to assess the role that Socioeconomic Status plays in family structure and interaction. Most often social class is treated as an independent variable, where researchers try to assess the impact that class has on some family phenomenon such as marital satisfaction, childrearing practices, or sexual behavior. However social class also can be a dependent variable, in which researchers try to determine the impact that other variables such as race and gender have on social class. In virtually every study, researchers ask respondents to indicate their social class in some way, so that they can determine the relationship of social class to the topic under study. A discussion of social class is important also because the opportunities and expectations of individuals are shaped to a great extent by the social class in which they are raised. To a certain degree, family dynamics are influenced by Socioeconomic Status. The interest activities, marital expectations and parenting practice of families in different social classes vary somewhat. Sociologists are fascinated with the ways in which socialization experience are influenced by the resources to which families have access (Bidwell and Vander Mey, 2000).

How do couple's financial resources affect marital adjustment and family functioning? Neither financial stability nor wealth can ensure marital satisfaction. However poverty can produce daunting challenges and serious problems for married couples ( Klebanov, Brooks-Gann, and Duncan, 1994; Voydanoff, 1990).

Without money, families live in constant dread of financial drains such as illness, layoffs, or broken appliances. Husbands tend to view themselves as poor providers and become hostile and irritable. Their hostility can undermine the warm, supportive exchanges that help sustain relationships. This problem is sometimes aggravated by disappointed wives who criticize their husbands. Spontaneity in communication may be impaired by an understandable reluctance to talk about financial concerns (Weiten and Lloyd, 2003).

Thus it is not surprising that serious financial worries among couples are associated with increased hostility in husbands, increased depression in wives, and lower marital 
happiness in both husbands and wives (White and Rogers, 2001). Similarly, husband's job insecurity is predictive of wives' reports of marital conflict and their thoughts of divorce (Fox and Chancey, 1998). Moreover evidence consistently demonstrates that the risk of separation and divorce increases as husband's income declines (Ono, 1998; South and Lloyd, 1995).

Even when financial resources are plentiful, money can be a source of marital strain. Quarrels about how to spend money are common and potentially damaging at all income levels. Pittman and Lloyd (1988), for instance, found that perceived financial stress (regardless of family's actual income) was associated with decreased marital satisfaction. Another study examined how happily married couples handled their money in comparison to couples that eventually divorced. In comparison to divorced couples, the happy couples engaged in more joint decision-making on finances. Thus the best way to avoid troublesome battles over money is probably to engage in extensive planning of expenditures together (Schaninger and Buss, 1986).

The frequency of divorce is higher in the working and lower classes than in the upper and middle classes. There are probably many reasons for this finding, but a key one appears to be the greater financial stress in lower socioeconomic strata (Rank, 2000).

Financial hardship can increase isolation, emotional stress, depression and lower selfesteem, which, in turn, can generate or exacerbate marital tensions. It is possible that concerns about income or insecure employment may underline some of the stresses and tensions in the relationship that contributed to its breakdown (Kinnunen and Pulkkinen, 1998; Yeung and Hofferth, 1998).

Marriage counseling and family support agencies have suggested that financial strains have a negative impact on relationships and family life (House of Representatives Standing Committee on Legal and Constitutional Affairs, 1998).

Demographic and life course characteristics most frequently linked to the risk of marriage breakdown and divorce include early age at marriage, cohabitation and pregnancy prior to marriage, low education and income, parental divorce, non-traditional family values, previous marriage, and womens' employment (Amato and Rogers, 1997; Glezer, 1994; Ono, 1998; Sarantakos 1994; White, 1990).

Some studies have attached great importance to financial problems as a reason for marriage dissolution (Burns, 1984; Cleek and Pearson, 1985, 1991). Carmichael et.al (1997) suggests that several of these demographic factors, such as young age at marriage, early pregnancy and low income, are interrelated. According to Kurdek (1993), in term of relationship dynamics, these demographic risk factors represent a general lack of preparation for or doubtful competency in performing marital roles or resolving interpersonal conflict constructively by either or both partners. 
Other studies (Kitson and Holmes, 1992; Burns, 1984; Cleek, and Pearson, 1991) have associated lower socioeconomic status with alcohol and physical/emotional abuse as a reason for marital breakdown.

According to Tallman and Morgner (1970), where you stand economically will have a strong influence on your lifestyle and therefore on your attitudes towards courtship, marriage and the family. Traditionally, feelings of incompatibility, changed interests, unfair division of labour, or no longer feeling romantically attached as reasons for leaving a marriage were considered more likely to be the province of those in higher Socioeconomic Status positions while partners with lower Socioeconomic Status would require more dire instrumental reasons, such physical violence, alcohol abuse or lack of financial support, to leave a marriage.

Class differences in divorce rates illustrate the importance of stratification to family life. It was once commonly assumed that divorce was a luxury primarily available only to those who could afford it. Therefore, it was concluded, lower status people either separate informally or continue to suffer (Glick, 1957). But now that better data are available, it is known that the divorce rate varies inversely with the class level; that is, the higher the class level, the lower the number of divorces per capita. Indeed by 1967 it is reported that the lower class divorce rate is more than twice as high as that among the middle class (O' Neill, 1967).

There are important social class differences related to adjustment in marriage. This is true because the worlds in which marriage takes place are often very different. For example, lower class men and women have a greater tendency to live in separate social and psychological worlds with limited communication in marriage. But in the middle class there is generally a great stress placed on communication and shared activities and these are seen as closely related to adjustment in marriage. These differences are also reflected in what is felt to be important in marriage by social class (Bell, 1983).

Financial woes are a source of relationship strain, Vinokur, Price and Caplan (1996) studied 815 recently unemployed people and their partners. Financial strain made both individuals more depressed and led them to withdraw socially and to undermine their significant others.

Working women with young children in families in which both spouses' earnings are low are much more likely to report depression than married men, full-time homemakers, or employed married women who have no child-care or economic problems (Verbrugge, 1979; Gove, 1984; Anson, 1989).

Chilman (1975) has identified some basic problems of poor families as a whole. A majority of them are locked in by their particular situation, especially minority families and those family units headed by a woman. She notes a number of problems associated with being at the bottom of the income scale. These families have difficulty in moving to a city or state where they might have a better chance for work. They do not know exactly where to go and lack money resources to hang on until a new job comes along. 
Some are old persons, who have great difficulty in getting jobs, or are past the retirement age. Poor families lack alternate incomes from savings, property, stock or other sources. Physical and mental health is often poor. There is frequent family breakdown as a result of separation, death and divorce. There is difficulty in effective family planning and these families cannot take advantage of educational opportunities, which are offered to them. All in all the entire picture is a very discouraging one. Family crises do not occur in these families, instead these families are in a constant crises state.

Money is a very common source of conflict. Arguments over money generally focus on how-- or how not-- to spend it. Conflicts over how money is spent may become particularly intense if a working wife has no input and feels that her husband's decisions are "unfair" (Blair, 1993). Income loss and insufficient financial resources are associated with family financial disputes and marital tensions (Nowak and Snyder, 1984).

Landis (1975) lists six areas of Marital Adjustment. They are religion, social life, mutual friends, in-laws, money and sex. Blood and Wolfe (1960) speak about eight areas of Marital Adjustment namely money, children, recreation, personality, in laws, roles, religion and sex. Mace (1982) sees ten areas of adjustment; values, couple growth, communication, conflict resolution, affection, roles, cooperation, sex, money and parenthood.

By observing two phenomenon i.e., economic problems and marital maladjustment in Pakistan, the question arises: whether there is any relationship between one's Socioeconomic Status and Marital Adjustment? The present research also investigated that whether the working women who belong to upper class would show better Marital Adjustment as compared to the working women coming from the middle and lower classes.

In the light of Literature review the following hypothesis was formulated:

Marital Adjustment would be more among working women of high Socioeconomic Status as compared to working women of low and middle Socioeconomic Status.

\section{METHOD}

\section{Sample}

The present research study is based on a sample of 150 married working women. The sample was further stratified into three groups of subjects each consisting of fifty married working women. These groups comprised of low, middle and high socioeconomic classes. The ages of the subjects ranged from 25 years to 45 years with a mean age of 34 years. They were married for an average of 10 years with a minimum of 2 years and a maximum of 26 years. The mean monthly incomes of the subjects belonging to low, middle and high socioeconomic status were Rs. 10,482, Rs. 26,500 and Rs. 67,160 respectively. Their minimum educational level was graduation. 
In order to avoid sampling error, respondents meeting the criteria but with these characteristics, were excluded from the sample a) respondents who did not complete questionnaires, b) respondents who were divorced, c) respondents who were not Pakistani nationals, d) respondents whose husbands were living abroad.

\section{Procedure}

The present study is based on a sample of 150 married working women divided into low, middle and high socioeconomic classes. Based on the data contained in the Household Income and Expenditure Survey conducted by the Federal Bureau of Statistics (FBS) Government of Pakistan (April 2001) the average monthly household income was Rs. 5,770 and the categorization of income was in 11 groups, ten of these groups falling in an income bracket of Rs. 7,000 per month and below.

In order to formulate income groups for our present study we made an analytical study of the household expenditures as revealed by the household income and expenditure survey and found out that a correct categorization of low socioeconomic class would be based on expenditure pattern specially food. The expenditure on food among the lower socioeconomic class was as high as 37\% to 50\% as per Household Income and Expenditure Survey. In order to refine the data gathered from this source we also reviewed some data gathered from unpublished sources i.e. surveys conducted by commercial banks for their internal consumption. Out of the 11 categories of income given by the Household Income and Expenditure Survey, we have clubbed together certain categories and classified them in three socioeconomic classes i.e., high, middle and low (the definitions of these three classes are given under the heading of "Operational Definitions of Various Terms").

In the present study both partner's incomes have been taken into consideration while measuring the Socioeconomic Status. Traditionally, the income level of the primary earner, usually the husband determined the Socioeconomic Status assigned to the family. This conventional method of determining a family's social class works well when husbands are the sole earners in the family. However, few families today are comprised of a breadwinning husband and a full-time homemaking wife. Measuring the Socioeconomic Status of a dual income couple using the husband's income, alone is problematic. Failure to acknowledge woman's work contribution in dual income couples can also give an inaccurate picture of family's material life-styles.

Data was collected from various hospitals, commercial and educational institutions of Karachi. Formal permission for data collection was taken by contacting the subjects in their respective workplaces.

The subjects first completed the personal information questionnaire and then the Dyadic Adjustment Scale (Spanier, 2001). 


\section{Scoring}

After collection of data the answer sheets were scored. The Dyadic Adjustment Scale was scored according to the instructions given in the manual.

\section{Statistical Analysis}

One-way Analysis of Variance (ANOVA) and Tukey's honestly significant difference test was done to compare the difference in the level of Marital Adjustment of working women belonging to low, middle and high Socioeconomic Status. Additionally oneway Analysis of Variance (ANOVA) and Tukey's honestly significant difference test was also done to compare the difference in the scores of the above three mentioned groups on the subscales of Dyadic Adjustment Scale.

\section{Operational Definitions of Various Terms}

Marital Adjustment: is calculated by adding the total scores of the subscales of Dyadic Adjustment Scale. The four subscales as defined by Spanier (2001) are as follows:

Dyadic Consensus: assesses the extent of agreement between partners on matters important to the relationship, such as money, religion, recreation, friends, household tasks, and time spent together.

Dyadic Satisfaction: measures the amount of tension in the relationship, as well as the extent to which the individual has considered ending the relationship. High scores on Dyadic Satisfaction indicate satisfaction with the present state of the relationship and commitment to its continuance.

Affectional Expression: measures the individual's satisfaction with the expression of affection and sex in the relationship.

Dyadic Cohesion: assesses the common interests and activities shared by the couple.

Low Socioeconomic Status: (Households having a monthly income of Rs. 14,000 and below) - This income group is categorized as people spending a very high percentage of their income on food, transport and house rent. Their expenditure on items relating to personal appearance, cleanliness and laundry is minimal. For education they depend on government subsidized institutions.

Middle Socioeconomic Status: (Households having a monthly income of Rs. 14,000 to 30,000$)$ - This group has a lesser amount of expenditure on food and spends more on personal appearance and education as compared to the lower socioeconomic group.

High Socioeconomic Status: (Households having a monthly income of Rs. 30,000 and above) - This class is categorized with people having a high emphasis on personal appearance, education and recreation as compared to the two above mentioned groups. 
Married Working Women: The married working women in the present research are defined as those married women who are working outside their homes for which they are paid.

\section{RESULTS}

Table 1a

Analysis of Variance among Low, Middle and High Socioeconomic Status on the Variable of Marital Adjustment

\begin{tabular}{|c|c|c|c|c|c|}
\hline Source & SS & df & Ms & F & Sig. \\
\hline Between & 238.840 & 2 & 119.420 & & \\
Within & 75845.320 & 147 & 515.955 & .231 & .794 \\
Total & 76084.160 & 149 & & & \\
\hline
\end{tabular}

$\mathrm{F}=.231$, df (2,147), p>.05 indicates insignificant difference among low, middle and high Socioeconomic Status on the variable of Marital Adjustment

Table 1b

Tukey's HSD Analyses showing mean differences among the three Socioeconomic Classes on the Variable of Marital Adjustment

\begin{tabular}{|c|c|c|c|c|c|c|}
\hline \multirow{2}{*}{\multicolumn{2}{|c|}{ (I) GROUP (J) GROUP }} & \multirow{2}{*}{$\begin{array}{l}\text { Mean } \\
\text { Difference } \\
\text { (I-J) }\end{array}$} & \multirow{2}{*}{ Std. Error } & \multirow{2}{*}{ Sig. } & \multicolumn{2}{|c|}{$\begin{array}{c}95 \% \text { Confidence } \\
\text { Interval }\end{array}$} \\
\hline & & & & & Lower & Upper \\
\hline \multirow{2}{*}{ Low } & Middle & -2.08 & 4.54 & 0.648 & -11.06 & 6.90 \\
\hline & High & 0.94 & 4.54 & 0.836 & -8.04 & 9.92 \\
\hline \multirow[t]{2}{*}{ Middle } & Low & 2.08 & 4.54 & 0.648 & -6.90 & 11.06 \\
\hline & High & 3.02 & 4.54 & 0.507 & -5.96 & 12.00 \\
\hline \multirow[t]{2}{*}{ High } & Low & -0.94 & 4.54 & 0.836 & -9.92 & 8.04 \\
\hline & Middle & -3.02 & 4.54 & 0.507 & -12.00 & 5.96 \\
\hline
\end{tabular}

Tukey's HSD indicates no significant mean differences among the three groups of Socioeconomic Status 
Table 1c

Table showing the Means, Standard Deviations and Standard Errors of Low, Middle and High Socioeconomic groups on the variable of Marital Adjustment

\begin{tabular}{|r|c|c|c|c|c|c|}
\hline \multicolumn{1}{|c|}{ Groups } & N & Mean & $\begin{array}{c}\text { Std. } \\
\text { Deviation }\end{array}$ & $\begin{array}{c}\text { Std. } \\
\text { Error }\end{array}$ & \multicolumn{2}{|c|}{$\begin{array}{c}\text { 95\% Confidence Interval } \\
\text { for Mean }\end{array}$} \\
\hline & & & & & $\begin{array}{c}\text { Lower } \\
\text { Bound }\end{array}$ & $\begin{array}{c}\text { Upper } \\
\text { Bound }\end{array}$ \\
\hline Low SES & 50 & 110.4600 & 27.0813 & 3.8299 & 102.7636 & 118.1564 \\
\hline Middle SES & 50 & 112.5400 & 19.8394 & 2.8057 & 106.9017 & 118.1783 \\
\hline High SES & 50 & 109.5200 & 20.5150 & 2.9013 & 103.6897 & 115.3503 \\
\hline Total & 150 & 110.8400 & 22.5972 & 1.8451 & 107.1942 & 114.4858 \\
\hline
\end{tabular}

Table 2a

Analysis of Variance among Low, Middle and High Socioeconomic Status on the subscales of Dyadic Adjustment Scale

\begin{tabular}{|c|c|c|c|c|c|c|}
\hline Variables & Source & SS & df & Ms & $\mathbf{F}$ & Sig. \\
\hline $\begin{array}{c}\text { Dyadic } \\
\text { consensus }\end{array}$ & $\begin{array}{c}\text { Between } \\
\text { Within } \\
\text { Total }\end{array}$ & $\begin{array}{c}94.653 \\
18229.620 \\
18324.273\end{array}$ & $\begin{array}{c}2 \\
147 \\
149\end{array}$ & $\begin{array}{c}47.327 \\
124.011\end{array}$ & .382 & .683 \\
\hline $\begin{array}{c}\text { Dyadic } \\
\text { Satisfaction }\end{array}$ & $\begin{array}{c}\text { Between } \\
\text { Within } \\
\text { Total }\end{array}$ & $\begin{array}{c}34.013 \\
10258.680 \\
10292.693\end{array}$ & $\begin{array}{c}2 \\
147 \\
149\end{array}$ & $\begin{array}{l}17.007 \\
69.787\end{array}$ & .244 & .784 \\
\hline $\begin{array}{l}\text { Affectional } \\
\text { expression }\end{array}$ & $\begin{array}{c}\text { Between } \\
\text { Within } \\
\text { Total }\end{array}$ & $\begin{array}{c}3.573 \\
1210.000 \\
1213.573\end{array}$ & $\begin{array}{c}2 \\
147 \\
149\end{array}$ & $\begin{array}{l}1.787 \\
8.231\end{array}$ & .217 & .805 \\
\hline
\end{tabular}


Table 2b

Tukey's HSD, showing mean differences among the three groups of Socioeconomic Status on the subscales of Dyadic Adjustment Scale.

Tukey's HSD

Multiple Comparisons

\begin{tabular}{|c|c|c|c|c|c|c|c|}
\hline \multirow[b]{2}{*}{$\begin{array}{l}\text { Dependent } \\
\text { Variable }\end{array}$} & \multirow[b]{2}{*}{$\begin{array}{c}\text { (I) } \\
\text { SES }\end{array}$} & \multirow[b]{2}{*}{$\begin{array}{c}(\mathbf{J}) \\
\text { SES }\end{array}$} & \multirow{2}{*}{$\begin{array}{c}\text { Mean } \\
\text { Difference } \\
\text { (I-J) }\end{array}$} & \multirow{2}{*}{$\begin{array}{l}\text { Std. } \\
\text { Error }\end{array}$} & \multirow{2}{*}{ Sig. } & \multicolumn{2}{|c|}{$\begin{array}{l}\text { 95\% Confidence } \\
\text { Interval }\end{array}$} \\
\hline & & & & & & $\begin{array}{l}\text { Lower } \\
\text { Bound }\end{array}$ & $\begin{array}{l}\text { Upper } \\
\text { Bound }\end{array}$ \\
\hline \multirow[t]{6}{*}{$\mathrm{DCN}$} & 1.00 & 2.00 & -.2600 & 2.2272 & .993 & -5.4799 & 4.9599 \\
\hline & & 3.00 & 1.5400 & 2.2272 & .768 & -3.6799 & 6.7599 \\
\hline & 2.00 & 1.00 & .2600 & 2.2272 & .993 & -4.9599 & 5.4799 \\
\hline & & 3.00 & 1.8000 & 2.2272 & .698 & -3.4199 & 7.0199 \\
\hline & 3.00 & 1.00 & -1.5400 & 2.2272 & .768 & -6.7599 & 3.6799 \\
\hline & & 2.00 & -1.8000 & 2.2272 & .698 & -7.0199 & 3.4199 \\
\hline \multirow[t]{6}{*}{ DS } & 1.00 & 2.00 & $2.000 \mathrm{E}-02$ & 1.6708 & 1.000 & -3.8958 & 3.9358 \\
\hline & & 3.00 & -1.0000 & 1.6708 & .821 & -4.9158 & 2.9158 \\
\hline & 2.00 & 1.00 & $2.0000 \mathrm{E}-02$ & 1.6708 & 1.000 & -3.9358 & 3.8958 \\
\hline & & 3.00 & -1.0200 & 1.6708 & .814 & -4.9358 & 2.8958 \\
\hline & 3.00 & 1.00 & 1.0000 & 1.6708 & .821 & -2.9158 & 4.9158 \\
\hline & & 2.00 & 1.0200 & 1.6708 & .814 & -2.8958 & 4.9358 \\
\hline \multirow[t]{6}{*}{$\mathrm{AE}$} & 1.00 & 2.00 & $8.0000 \mathrm{E}-02$ & .5738 & .989 & -1.4248 & 1.2648 \\
\hline & & 3.00 & .2800 & .5738 & .877 & -1.0648 & 1.6248 \\
\hline & 2.00 & 1.00 & $8.000 \mathrm{E}-02$ & .5738 & .989 & -1.2648 & 1.4248 \\
\hline & & 3.00 & .3600 & .5738 & .805 & -.9848 & 1.7048 \\
\hline & 3.00 & 1.00 & -.2800 & .5738 & .877 & -1.6248 & 1.0648 \\
\hline & & 2.00 & -.3600 & .5738 & .805 & -1.7048 & .9848 \\
\hline \multirow[t]{6}{*}{$\mathrm{DCH}$} & 1.00 & 2.00 & -1.8400 & 1.0988 & .215 & -4.4153 & .7353 \\
\hline & & 3.00 & -.9400 & 1.0988 & .668 & -3.5153 & 1.6353 \\
\hline & 2.00 & 1.00 & 1.8400 & 1.0988 & .215 & -.7353 & 4.4153 \\
\hline & & 3.00 & .9000 & 1.0988 & .691 & -1.6753 & 3.4753 \\
\hline & 3.00 & 1.00 & .9400 & 1.0988 & .668 & -1.6353 & 3.5153 \\
\hline & & 2.00 & -.9000 & 1.0988 & .691 & -3.4753 & 1.6753 \\
\hline
\end{tabular}

1= Low Socioeconomic Status, 2= Middle Socioeconomic Status, 3= High Socioeconomic Status, DCN= Dyadic Consensus, DS= Dyadic Satisfaction, AE= Affectional Expression, DCH= Dyadic Cohesion 


\section{DISCUSSION}

The results of the research show that the difference between marital adjustment of the three groups is not significant, $\mathrm{F}=.231$, df $(2,147), \mathrm{p}>.05$, (Table 1a). Tukey's Honestly Significant Difference test (Table 1b) also shows that there is no significant difference between Marital Adjustment of working women belonging to middle and high Socioeconomic Status ( $p>.05$ ), low and high Socioeconomic Status ( $p>.05)$, and low and middle Socioeconomic Status ( $\mathrm{p}>.05$ ). However (Table 1c) shows that working women belonging to high socioeconomic class (109.5) have a marginally lower level of Marital Adjustment as compared to women belonging to middle (112.5) and low (110.46) Socioeconomic Status. There is also no significant difference found between working women belonging to low, middle and high Socioeconomic Status on the subscales (Dyadic Consensus, Dyadic Satisfaction, Dyadic Cohesion and Affectional Expression) of Dyadic Adjustment Scale (Table 2a \& 2b).

Money is the one thing that people say they argue about most in marriage, followed by children (Stanley \& Markman, 1997). But, there is a lot of reason to believe that what couples argue about is not as important as how they argue (Markman, Stanley, $\&$ Blumberg, 1994). The way finances are handled in a marriage can represent underlying issues of power and authority in a relationship that may contribute to overall dissatisfaction.

The results of the research show that the difference between the Marital Adjustments of the three groups is not significant however working women belonging to high socioeconomic class have a marginally lower level of Marital Adjustment. The problems faced by married working women belonging to all three groups were quite similar. All the family members enjoy the economic advantages that their job brings, but dislike their changing role and status at home. They do not accept their neglecting traditional roles as result of their employment. A Pakistani woman gets more respect for her role rather than as a person. In few cases, however, working wives begin to think that they are not obliged to tolerate their "socially defined position" and believe themselves as capable as their husbands. This may hurt the male ego of Pakistani husbands, and thus bring multiple tensions to the marital relationship. Most of the respondents reported that they experienced an incompatible attitude of their spouses and other family members towards their multiple roles and status complex. This leads to less intimacy, sharing and talking on a daily basis.

According to Palen (1976), the situation of the upper class woman is rather different. Such women demand a high degree of independence while also expecting to find selffulfillment in marriage. If they suffer disappointment on either of these counts or if the marriage interferes with their personal development or career, they may be more willing to consider divorce, since they are financially independent to afford it. This could be one of the reasons why the working women belonging to high Socioeconomic Status were not as adjusted in their marriages as the women belonging to middle and low class. Increased income can allay stresses caused by financial problems, but 
tensions may increase when the division of household responsibilities is considered to be a burden on one spouse (Heaton and Blake, 1999).

In the present research the working women belonging to high Socioeconomic Status were highly educated and held a post-masters degree and had better incomes through their jobs. Therefore these women, in particular, increasingly reject the impersonal, tension-filled, and emotionally unfulfilling marriages that were taken for granted by some of our grandparents or even our parents. With education and occupation in their hands, these women do not need to rely on men for economic support, thus marriage is not an immediate concern anymore. One of the most likely reasons for their decline in Marital Adjustment is an increase in what they expect of marriage. Women belonging to high Socioeconomic Status expect greater levels of intimacy, emotional support, companionship, and sexual gratification, which eventually lead to discord and disappointment. One common assumption is that when wives increase their income, they are preparing for a divorce and independent living by reducing the economic barriers holding both spouses in the marriage (Levinger, 1976). Previous research provides support for the association between married women's economic resources and eventual divorce (Booth et al., 1984; Heidemann, Suhomlinova and O'Rand, 1998). Studying long-term marriages, Heidemann and colleagues indicate that increases in wives' employment or wages increase the probability of marital disruption.

The female interviewees belonging to high Socioeconomic Status believed that men think they are taking over male professional roles. This threatens men's sense of patriarchal power, and leads to marital disharmony. These working women also agree with their husbands that jobs empower women. The wives sense their husband's fear but surprisingly, these women themselves are not glad of it, due to the negative impact on their marital harmony. The women belonging to high Socioeconomic Status had similar income and education levels as their husbands. Kapur's (1970) data suggested that as long as the wife's job status, income, and total number of hours worked do not exceed their husband's, the degree of conflict may not be that acute. Like Kapur's work, the results of the present research also showed that the working wives who are superior to their husbands in educational and income levels, they are likely to suffer more tension and dissatisfactions in their married life. That means the more a working wife is successful in her job, the more she loses her success as a wife. Whereas, a successful man in his job will make him a desirable husband. It supports our traditional view that male to have a career and the female a job. Which implies that the males must have greater economic resources and powerful roles than the females.

An increase in wives' financial resources may affect subsequent marital quality by influencing marital power dynamics. Having more resources may encourage wives to initiate change in power relations, in the household divisions of labour, and in spousal roles more generally (Blood and Wolf, 1960; Blumstein and Schwartz, 1983). Although there is not a significant difference found in the Marital Adjustment of working women belonging to low, middle and high Socioeconomic Status, the results of the research indicate that women belonging to high socioeconomic class have the lowest level of Marital Adjustment. 
Considerable shifts in power in the husband-wife relationship seem to occur when the wife is employed. In general the wife's power tends to increase. Thus, as the wife becomes employed she gains income independence and new contacts (resources) that increase her contribution to the marriage.

\section{REFERENCES}

Amato, P., \& Rogers, S. (1997). “A Longitudinal Study of Marital Problems and Subsequent Divorce", Journal of Marriage and the Family, 59, 612-624.

Anson, O. (1989). "Marital Status and Women's Health Revisited: The Importance of a Proximate Adult", Journal of Marriage and the Family, 51, 185-94.

Beach, S.R.H., Whisman, M.A., \& O’Leary, K.D. (1994). "Marital Therapy for Depression: Theoretical Foundation, Current Status, and Future Directions", Behavior Therapy, 25, 345-371.

Bell, R. R. (1983). "Marriage and Family Interaction”, 6th edition, Illinois: The Dorsey Press.

Bidwell, L.D.M. and Mey, B.J.V. (2000). "Sociology of the Family: Investigating Family Issues", Boston: Allyn and Bacon, pp 151.

Blair, S.L. (May 1993). "Employment, Family, and Perceptions of Marital Quality Among Husbands and Wives", Journal of Family Issues, 14(2), 189-212.

Blood, R.O., \& Wolfe, D. (1960). "Husbands and Wives: The Dynamics of Married Living", New York: Free Press.

Blumstein, P., \& Schwartz, P. (1983). “American Couples: Money, Work, Sex”, New York: William Morrow.

Booth, A., Johnson, D.R., White, L.K., \& Edwards, J.N. (1984). "Women, Outside Employment and Marital Instability”, American Journal of Sociology, 90, 567-583.

Burns, A. (1984). "Perceived Cause of Marriage Breakdown and Conditions of Life", Journal of Marriage and the Family, 46, 551-562.

Carmichael, G., Webster, A. \& McDonald, P. (1997). Divorce Australian Style: A Demographic Analysis", Journal of Divorce and Remarriage, 26(3/4), 3-37.

Chilman, C.S. (1975 Feb). "Families in Poverty in the early 1970's: Rates, Associated Factors, Some Implications", Journal of Marriage and the Family, 37(1), 49-60.

Cleek, M. \& Pearson, T. (1991). "Demographic Subgroup Contributions to Divorce Cause Constellations", Journal of Divorce and Remarriage, 15, 33-49. 
Cleek, M. \& Pearson, T. (1985). "Perceived Cause of Divorce: An Analysis of Interrelationships", Journal of Marriage and the Family, 47, 179-183.

Federal Bureau of Statistics (April 2001). "Household Income and Expenditure Survey", Government of Pakistan.

Fox, G.L. \& Chancey, D. (1998). "Sources of Economic Distress: Individual and Family Outcomes", Journal of Family Issues, 19, 725-749.

Glezer, H. \& Wolcott, I. (1999), "Work and Family Life: Reciprocal Effects”, Family Matters, 52, 69-74.

Glick, P.C. (1957). American Families, New York: John Wiley and Sons, Inc.

Gove, W.R. (1984). "Gender Differences in Mental and Physical Illness: The Effects of Fixed Roles and Nurturant Roles", Social Science and Medicine 19, 77-84.

Heaton, T. \& Blake, A. (1999), "Gender Differences in Determinants of Marital Disruption", Journal of Family Issues, 20(1), 25-45.

Heidemann, B., Suhomlinova, O. \& O'Rand, A. (1988). "Economic Independence, Economic Status and Empty Nest in Midlife Marital Disruption”, Journal of Marriage and the Family, 60, 219-231.

House of Representatives Standing Committee on Legal and Constitutional Affairs. (1998), “To Have and to Hold: Strategies to Strengthen Marriage and Relationships", Parliament of the Commonwealth of Australia, Canberra.

Kahl, J. (1957). The American Class Structure, New York: Holt, Rinehart, and Witson.

Kapur, P. (1970). Marriage and the Working Women in India, Delhi: Vikas Publishers.

Kinnunen, U. \& Pulkkinen, L. (1998). "Linking Economic Stress to Marital Quality Among Finnish Marital Couples”, Journal of Family Issues, 19(6), 705-724.

Kitson, G. \& Holmes, W. (1992). Portrait of Divorce: Adjustment to Marital Breakdown, New York: Guilford Press.

Klebenov, P.K., Brooks-Gunn, J. \& Duncan, G.J. (1994). "Does Neighborhood and Family Poverty Affect Mothers' Parenting, Mental Health, \& Social Support?”, Journal of Marriage and the Family, 56, 441-455.

Kurdek, L. (1993), "Predicting Marital Dissolution: A Five-year Prospective Longitudinal Study of Newlywed Couples", Journal of Personality and Social Psychology, 64(2), 221-242.

Landis, J.T. (1975). "Personal Adjustment, Marriage, and Family", 6th edition, New York: Harper \& Row Publishers. 
Levinger, G. (1976). “A Socio-psychological Perspective on Marital Dissolution", Journal of Social Issues, 52, 21-47.

Mace, D.R. (1982). Close companions: The marriage enrichment handbook. New York: The Continuem Publishing Company.

Markman, H.J., Stanley, S.M. \& Blumberg, S.L. (1994). Fighting for Your Marriage: Positive Steps for a Loving and Lasting Relationship, San Francisco: Jossey Bass, Inc.

Nowak, T.C. \& Snyder, K.A. (1984). "Job Loss, Marital Happiness and Household Tension: Do Women Face Better than Men?" Paper presented at the annual meeting of the society for the study of social problems.

O' Neill, W. L. (1967). Divorce in the Progressive Era, New Haven: Yale University Press.

O’Leary, K.D., \& Smith, D.A. (1991). Marital Interactions. Annual Review of Psychology, 42, 191-212.

Ono, H. (1998). "Husbands' and Wives' Resources and Marital Dissolution”, Journal of Marriage and the Family, 60, 674-689.

Palen, J. J. (1976). Social Problems, McGraw-Hill, pp. 326-27.

Pittman, J.F. \& Lloyd, S.A. (1988). "Quality of Family Life, Social Support, and Stress", Journal of Marriage and the Family, 50, 53-67.

Rank, M.R. (2000). "Poverty and Economic Hardship in Families”. In D.H. Demo, K.R. Allen \& M.A. Fine (Eds.), Handbook of family diversity (pp. 293-315), New York: Oxford University Press.

Sarantakos, S. (1994). "Trial Cohabitation on Trial”, Australian Social Work, 47(3), 13-25.

Schaninger, C.M. \& Buss, W.C. (1986). “A Longitudinal Comparison of Consumption and Finances Handling between Happily Married and Divorced Couples", Journal of Marriage and Family, 48, 129-136.

Sinha, S.P. \& Mukerjee, N. (1990). "Marital Adjustment and Space Orientation”, The Journal of Social Psychology, 130(5), 633-639.

South, S.J. \& Lloyd, K.M. (1995). "Spousal Alternatives and Marital Dissolution", American Sociological Review, 60, 21-35.

Spanier, G.B. \& Cole, C.L. (Spring 1976). “Toward Clarification Investigation of Marital Adjustment", International Journal of Sociology of the Family, 6(1), 127-128. 
Stanley, S.M. \& Markman, H.J. (1997). Marriage in the 90s: A Nationwide Random Phone Survey, Denver, Colorado: PREP, Inc.

Tallman, I. \& Morgner, R. (1970). "Life -style Differences Among Urban and Suburban Blue-collar Families", Social Forces, 48(3), 334-48.

Verbrugge, L. (1979). "Marital Status and Health", Journal of Marriage and the Family, 41 (May), 267-85.

Vinokur, A.D., Price, R.H. \& Caplan, R.D. (1996). "Hard Times and Hurtful Partners: How Financial Strain Affects Depression and Relationship Satisfaction of Unemployed Persons and their Spouses", Journal of Personality and Social Psychology, 71, 166179 .

Voydanoff, P. (1990). "Economic Distress and Family Relations: A Review of the Eighties", Journal of Marriage and Family, 52, 1099-1115.

Warner, W., Weeken, M. \& Eels, K. (1949). Social Class in America, Chicago: Science Research.

Weiten, W. \& Lloyd, M.A. (2003). Psychology Applied to Modern Life: Adjustment in the 21st Century, 7th edition, Australia: Thomson Wadsworth.

White, L. (1990). "Determinants of Divorce: A Review of Research in the Eighties", Journal of Marriage and the Family, 52, 904-912.

White, L.K. \& Rogers, S.J. (2001). Economic Circumstances and Family Outcomes: A Review of the 1990s. In R.M. Milardo (Ed.), Understanding Families into the New Millennium: A Decade in Review (pp. 254-270). Minneapolis, MN: National Council on Family Relations.

Yeung, J. \& Hofferth, S. (1998). "Family Adaptations to Income and Job Loss in the U.S.”, Journal of Family and Economic Issues. 19(3).

"If the feudal Knight was the clearest embodiment of society in the early Middle Ages, and the 'bourgeois' under Capitalism, the educated person will represent society in the post-capitalist society in which knowledge has become the central resource."

Drucker, P. Post Capitalist Society. 